\title{
Development of extensional stresses in the compressional setting of the Himalayan thrust wedge: inference from numerical modelling
}

\author{
Ganesh Raj Joshi*, Daigoro Hayashi \\ Simulation Tectonics Laboratory, University of the Ryukyus, Okinawa, Japan; *Corresponding Author: ganeshr joshi@hotmail.com
}

Received 16 March 2010; revised 10 May 2010; accepted 15 May 2010.

\begin{abstract}
The estimation of contemporary tectonic stress field and deformation in active fold-and-thrust belts are imperative in identifying active geodynamics and resulting faulting phenomenon. In this paper, we focus on contemporary extensional tectonics in the overall compressive setting of the Himalayan orogen. Here we examine the regional tectonic stress field and upper crustal deformation in the Himalayan thrust wedge using a 2D finite element technique, incorporating elastic rheology under plain strain condition. The elastic models demonstrate that the extensional tectonic stress and related normal faulting is extensively developed in the southern front of the Himalaya at shallow crustal level (<10 km in depth). Our modelling shows a good consistency with the geological field evidences of active faulting, focal mechanism solutions of medium size earthquakes in the several sectors of the Himalaya. Results based on numerical simulation, tectonic analysis and taking geological and geophysical data into account, we interpret that the present-day extensional tectonic activity is not restricted in the southern Tibet but distributed in the different sectors of the Himalayan fold-and-thrust belt co-exist with compressional structures. Modelling results also indicate that the nature, distribution and orientation of the maximum compressive stress $\left(\sigma_{1}\right)$ of the Himalaya are mainly controlled by the intra crustal Main $\mathrm{Hi}-$ malayan décollement (MHT). The significant amount of shear stress/strain concentration along the MHT in the western Nepal predict that the region is prone to moderate and great future earthquakes.
\end{abstract}

Keywords: Extensional Stress Field; Convergent
Displacement; Finite Element Modelling; Himalayan Wedge

\section{INTRODUCTION}

The existence of syn-orogenic extension is relatively new discovery, which was described only since the eighties and has received quite a lot of attention in the past two decades. Understanding the mechanisms that produce extensional deformation in contractional orogenic belts is a major issue in the study of the plate continental structure and its dynamics. During the past few decades, extensional deformation structures have been mapped in several contractional orogen such as the eastern Alps [1], Andean Cordillera [2], Southern Apennines [3], Scandinavian Caledonides [4], North American Cordillera [5], and the Himalayan orogen [6-8]. Generally, the normal faults appear to be late stage or post-orogenic structures, while documented cases of syn-orogenic normal faulting are less common, which does not fit readily into the paradigm of plate tectonics [9].

The Himalayan continental collision is formed as a result of collision between Indian and Eurasian landmasses ca 65-40 Ma ago [10]. The dominant structures of the Himalayan chain show a stack of large southvergent thrust sheets emplaced successively from north to south [11] and bounded by major intra-crustal thrusts. These intra-continental tectonic features, general seismic phenomenon, major folds and other deformation structures indicate the predominantly compressional tectonic regime of the Himalaya. However, lately, a variety of extensional expressions and normal faults have been recognized in the southern Tibet $[6,12,13]$. Although it is believed that these extensional structures are generally restricted only in the southern Tibet [6,12]; however, recent research has shown that normal faults and other extensional features are not restricted only within southern Tibet but distributed in the several sectors of the Himalaya [14-19]. These extensional features, however, are 
not obviously consistent with the dominant seismicity and southward thrusting of the Himalaya. Moreover, the mechanism and the kinematics leading to the formation of orogen-parallel extensional structures are still little understood. Therefore, it is important to understand the cause of ongoing paradoxical extensional tectonic activities in the overall compressive setting of the Himalaya.

Compared to other techniques, numerical modelling is a fast, more economical and powerful tool which allows for various geological structures and deformation phenomenon to be modeled in the full scale. Stress and strain values can be computed over long time periods using various constitutive laws [20]. Thus, numerical models have long been used to develop our understanding of the mechanics of crustal deformation [7,21-24] but most of these studies have been focus on the northern part of the Himalaya and no one describes about the extensional tectonic activities in the Himalayan front.

In this paper, we primarily focus on present-day ongoing extensional tectonics evidences in the southern part of the Himalayan fold-and-thrust belt applying a 2D finite element model (FEM). The final goal of this kind of work is to understand the possible mechanism that responsible for the development of the extensional stress and normal faulting in the overall compressive setting of the Himalaya thrust wedge.

\section{TECTONIC SETTING}

The Himalayas, one of the most seismo-tectonically active regions of the world, are generally defined as a 2500 $\mathrm{km}$-long arc of mountains stretching between Namche Barwa in the east and Nanga Parbat in the west. The Himalaya can be subdivided into western, central and eastern sectors on the basis of variations in regional geomorphology. This study focuses on the central sector of the Himalayan fold-and-thrust belt, between $76^{\circ} \mathrm{E}$ and $91^{\circ} \mathrm{E}$ (Figure 1). From the south of the STDS the geological structure and tectonic setting of the fold-andthrust belt of the Himalayas are mainly characterized by several prominent south-vergent thrust structures. These intra-continental structural features are the Main Central thrust (MCT), Main Boundary thrust (MBT) and the Himalayan Frontal thrust (HFT) from north to south, respectively. These north-dipping thrust faults have a southward transport direction, and are inferred to branch from the décollement thrust known as the Main Himalayan Thrust (MHT), which marks the underthrusting of the Indian lithosphere beneath the Himalaya and Tibet [25]. Several geological cross-sections across the Himalaya as well as seismic and other geophysical data suggest that a crustal ramp is present on the MHT [26,27]. Numerous studies indicating lateral variations in the geometry of the MHT décollement from east to west in the Himalaya [25,28,29]. This lateral disparity of MHT ramp geometry is the main cause for the abrupt change in topographic relief, variation of elastic strain/stress and intense seismic activities of the Himalaya [28,30].

The STDS is an east striking, north dipping system of the normal faults that extends at least $700 \mathrm{~km}$ and probably through the entire length of the northern front of the Himalaya orogen, initiated during the Miocene and contemporaneous with the MCT [5,13,21,22]. The MCT is the large-scale high strain zone that commonly occurs along the base of ductile shear zone and inverted metamorphism sequence, which places Tertiary metamorphic rocks of the Great Himalayan sequence over weakly metamorphosed the Precambrain-Paleozoic rocks

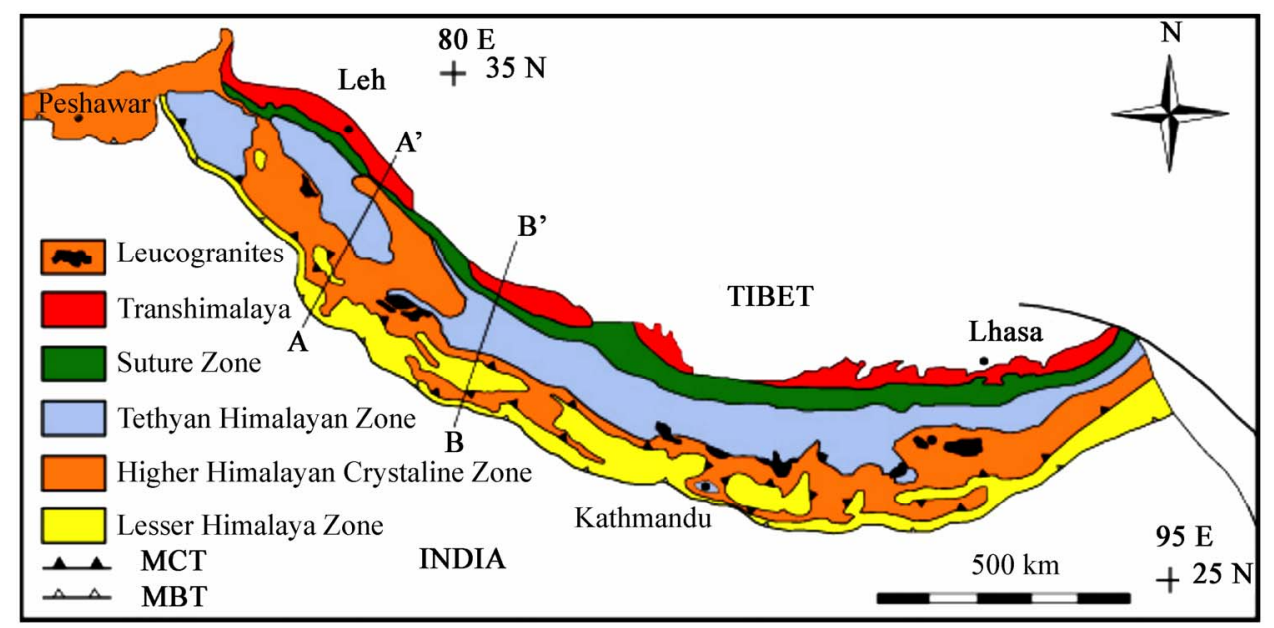

Figure 1. Geological map of the Himalaya showing major structural elements (MBT-Main Boundary Thrust, MCT- Main Central Thrust) (adopted from Lefort, 1988) and tentative locations of regional geological cross-sections lines A-A' and B-B'. 
of the Lesser Himalaya [31]. The MBT, a regional-scale sinuous, steeply north-dipping active thrust zone, separates folded and faulted Miocene and younger molasse sediments of the Sub-Himalaya from Precambrian rocks of the Lesser Himalaya [27]. Deformation of the MBT began before $10 \mathrm{Ma}$ [32]. However, several active fault systems are commonly associated with the MBT system, implying significant reactivation along many of its segments [15,33,34]. The MBT shows a down-to-the-north displacement in the central and western sector of the Himalaya $[14,15]$. The HFT is the southernmost, youngest, non-continuous, NW-SE striking and recently the most active imbricate thrust system in the Himalaya $[14,29]$. The HFT is a series of thrust faults that separate the Tertiary assemblage of the Sub-Himalaya from Quaternary sediments of the Ganga foreland basin.

\section{EVIDENCE FOR AN EXTENSIONAL REGIME AND NORMAL FAULTING}

\subsection{Geometry and Pattern of Active Normal Faulting}

In the overall compressional tectonic regime of the Himalaya, numerous contradictory orogen parallel and perpendicular microscopic to mesoscopic evidences of normal faults are well distributed. There are two main types of normal faults that developed in the Himalayan orogen; the first are the east-west striking, shallowly north-dipping, normal faults of the STDS and Zanskar shear zone which developed during the Early Miocene [8], while the second are relatively active and younger age normal faults which mainly restricted south of the MCT and associated with the mega thrust systems in the Himalayan $[14,15,19,33]$. In this section, we focus particularly on the evidence for syn-orogenic normal faulting and extensional tectonic structures and their significance are discussed in order to explain ongoing extensional tectonic activity at the overall compressive setting of the Himalaya.

Several normal faults on mesoscopic scale are observed in the Panjal Thrust Zone in the Dalhousie area of western Himachal [16]. Similarly, on the basis of field mapping and shear sense criteria Thakur et al. (1995) found that the boundary between the southern margin of the Higher Himalaya Crystalline (HHC) of Zanskar and the Chamba syncline sequence is a normal fault. The NW-SE and NNW-SSE oriented Karcham normal fault (KNF) (Figure 2) and the regional scale, steeply southdipping Bhadarwas normal fault are found in the central Hi machal. Regional scale normal faults are also observed in the Pinjor Thrust Zone in the Lesser Himalaya [16]. In the Kala Amb area, the NE-SW to E-W trending

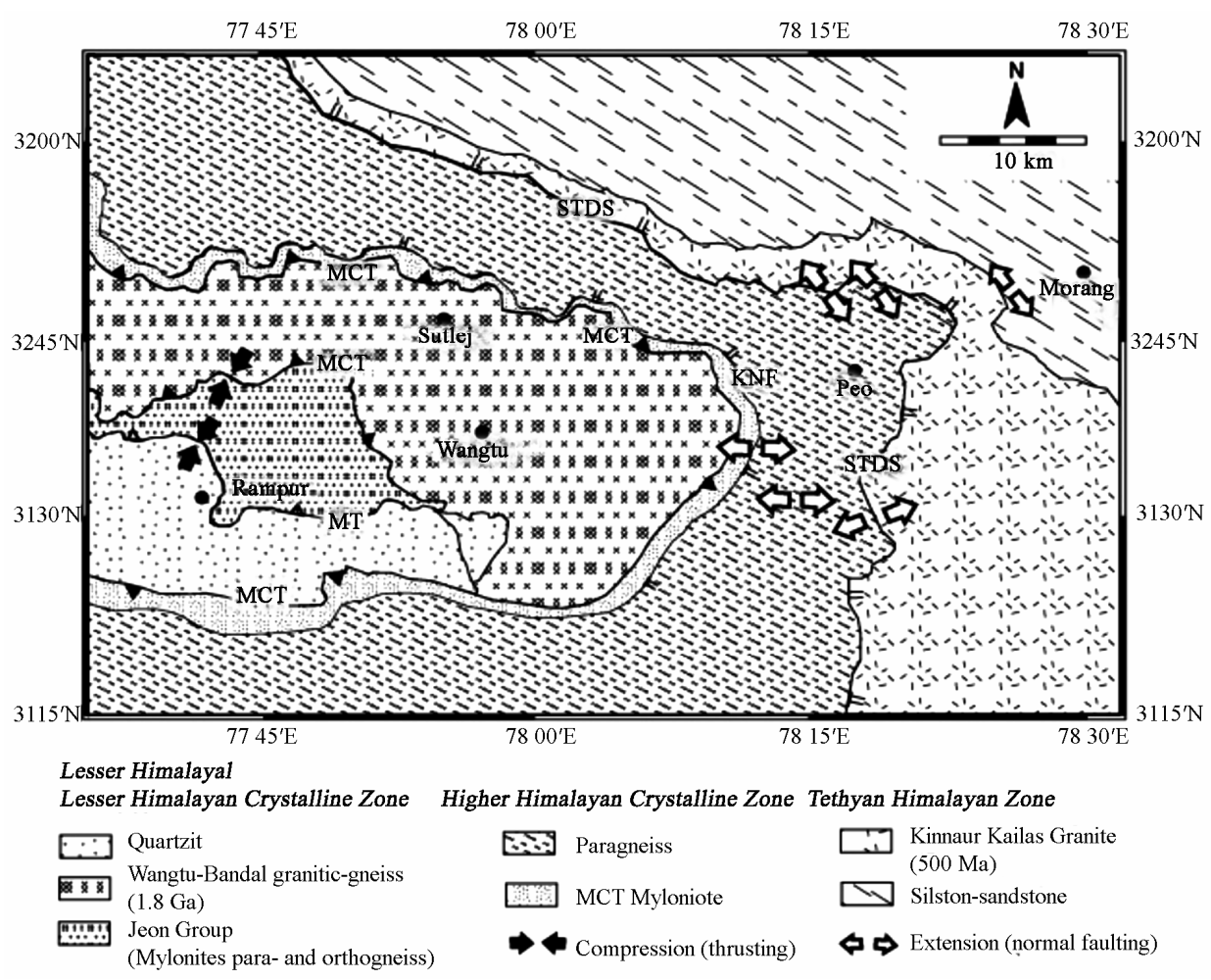

Figure 2. Geological map of the NW-Himalaya showing main faulting regime deduced from the fault-slip analysis adopted from the Vanney et al., 2004. 
Singhauli Active fault (SAF) shows normal faulting [35]. Near the southern termination of the SAF, another set of WNW-ESE trending south-side-up normal faults that dip steeply toward the northeast with well-defined fault scarps are observed [19]. In the Garhwal Himalaya, up to $40 \mathrm{~km}$ long, E-W to NW-SE trending, northward dipping Donga and Asan normal faults are well developed parallel to the MBT, while the NE-SW trending Kalsi normal fault is perpendicular to the MBT [33]. Similarly, the Surkhet-Ghorahi fault emerges as a single, continuous, steeply-dipping normal fault extends about $90 \mathrm{~km}$ long parallel to the MBT system in western Nepal, [15] (Figure 3).

\subsection{Geomorphologic Features}

Geomorphic and morphotectonic analysis of the landform further provide insights into style and pattern of ongoing tectonic deformation. The Himalayan fold-andthrust belt is characterized by several landforms produced by active tectonics along the mega thrust systems. The field observations in the different parts of centre Himalaya reveal that advancement of large scale lineaments, tilting and shifting of river and piedmont, subsidence of land and older rock sequences, uplift of river terraces and overriding of younger (Holocene) sediments by active thrusts and normal faults noticeably indicate the co-existence of compressional as well as extensional regimes in the Himalaya [19,36,37]. Moreover, the number of places just adjacent to the MBT and HFT, which defines the zone of convergent between Himalaya and Indo-gangetic plains, evidence of active normal faulting occurs [36]. These faulting have produced several topographic and geomorphic features such as active fault traces, lateral offsets of streams, offset of quaternary terraces, linear valleys running along faults and narrow, deep gorges in the Himalayan front [19,36,37], and suggest that the overall compressive setting of the Himalaya front contradictory exhibit extensional tectonic activities in the several parts.

\section{FINITE ELEMENT MODELLING}

In this paper, a 2D finite element (FE) technique has been used to simulate the present-day tectonic stress field and deformation of the Himalayan orogenic wedge using a software package developed by Hayashi [38]. The important part of the mathematical formulations about the software is provided and successfully applied in previous studies [12,38-40].

\subsection{Fault Analysis}

It is well-known fact that elastic deformations, even if small, govern the initiation of fault in nature [21]. Faulting observed in nature is in very good agreement with the simulated stress distribution for elastic models [41]. Therefore, elastic models have been considered in studying the development of extensional deformation in the overall compressive setting of the Himalaya. The models assume elastic rheology for the brittle upper crust of the Himalaya. Brittle failure is determined by the MohrCoulomb failure criterion, which is based on a linear relation between the shear stress $(\tau)$ and the normal stress $\left(\sigma_{n}\right)$ which can be express by following equation.

$$
\tau_{\text {failure }}=c+\sigma_{n} \tan \varphi
$$

where, $c$ is the cohesive strength and $\phi$ is the angle of internal friction. Failure occurs when the Mohr circle first touches the failure envelope. This occurs when the radius of the Mohr circle, $\left(\sigma_{1}-\sigma_{3}\right) / 2$, is equal to the perpendicular distance from the center of the circle at $\left(\sigma_{1}+\sigma_{3}\right) / 2$ to the failure envelope which is given by

$$
\left(\frac{\sigma_{1}-\sigma_{3}}{2}\right)_{\text {failure }}=c \cos \phi+\left(\frac{\sigma_{1}+\sigma_{3}}{2}\right) \sin \phi
$$

According to Melosh and William (1998), the prox-

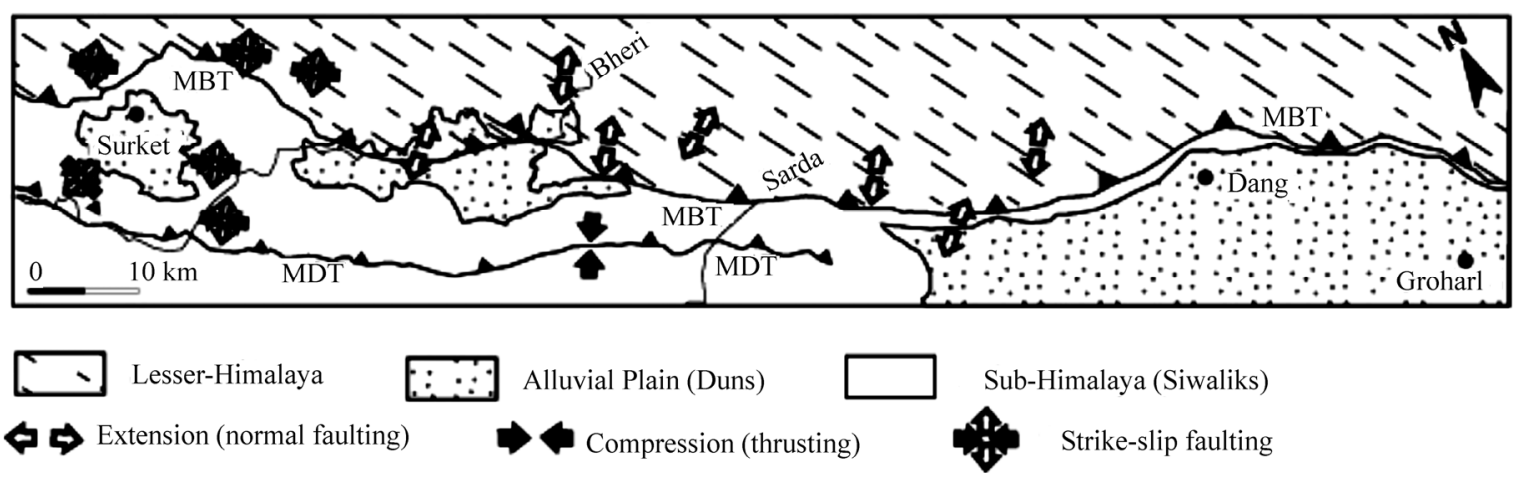

Figure 3. Geological map of the Surkhet-Goarahi fault in the western Nepal Himalaya showing main faulting regime deduced from slickenside analysis adopted from Mugnier et al., 2004. 
imity to failure $\left(P_{f}\right)$ is the ratio between the calculatedstress and failure stress can be express by

$$
P_{f}=\left[\frac{\left(\frac{\sigma_{1}-\sigma_{3}}{2}\right)}{\left(\frac{\sigma_{1}-\sigma_{3}}{2}\right)_{\text {failure }}}\right]
$$

When the ratio reaches $P_{f}=1$, failure occurs, but when $P_{f}<1$ stress is within the failure envelope rocks does not fail. The proximity to failure reveals which part of the model is close to failure or already failed by generating faults.

\subsection{Model Set-Up and Assumptions}

We adopted two N-S regional structural cross-sections through the Himachal Himalaya and western Nepal Himalaya for modelling. The NW-Himalaya model extends up to $200 \mathrm{~km}$ in length, with a maximum thickness of 40 $\mathrm{km}$ in the north, and the western Nepal model is $272 \mathrm{~km}$ in length and up to $40 \mathrm{~km}$ thick in the northern part (Figure 4). The major tectonic units and the approximate locations of the profiles are reported in Figure 1. Each cross-section is divided into different layers that represent major structural and lithological units according to their regional setting in the Himalaya. The convergence displacement has been applied, instead of stress and forces because the relative velocity of the Indian plate with respect to Eurasian plate for the central Himalaya is well constrained. The basement fault (MHT) is introduced with a prescribed geometry (Figure 4). Studies of the focal mechanism of the large earthquakes in the Himalaya [43] suggest that the MHT dips gently $4^{\circ}$ to $9^{\circ}$ from south to north [30], which is consistent with the INDEPTH profile [25] and topographic studies of the Himalaya [44]. For simplicity, we adopted dip angles $7^{\circ}$, $5^{\circ}$ and $30^{\circ}$ for the northern flat, southern flat and the MHT ramp, respectively [30]. Here, only the brittle portion of the MHT is prescribed. In our model, the crust up to $40 \mathrm{~km}$ is assumed to behave as an elastic material because of intense seismicity and generate several faults suggest the brittle characteristics of upper crust in the Himalaya.

\subsection{Boundary Conditions}

The Indian plates moves at $\mathrm{N} 20^{\circ} \mathrm{E}$ with constant rate of the convergence displacement relative to Eurasia [45], and subducts along a shallow dipping detachment known as the MHT beneath the Himalaya, and it is still continuing [25]. This continuous horizontal displacement caused by convergence of Indian plate has been considered as a prime driving force for the overriding crustal deformation of the Himalayan orogen. Therefore, simulation of the observed tectonic features of the Himalaya using appropriate boundary condition could be modeled by applying a horizontal convergence displacement from the southern face of the model with present-day shorting rate of the central Himalaya. Since the rate of displace-

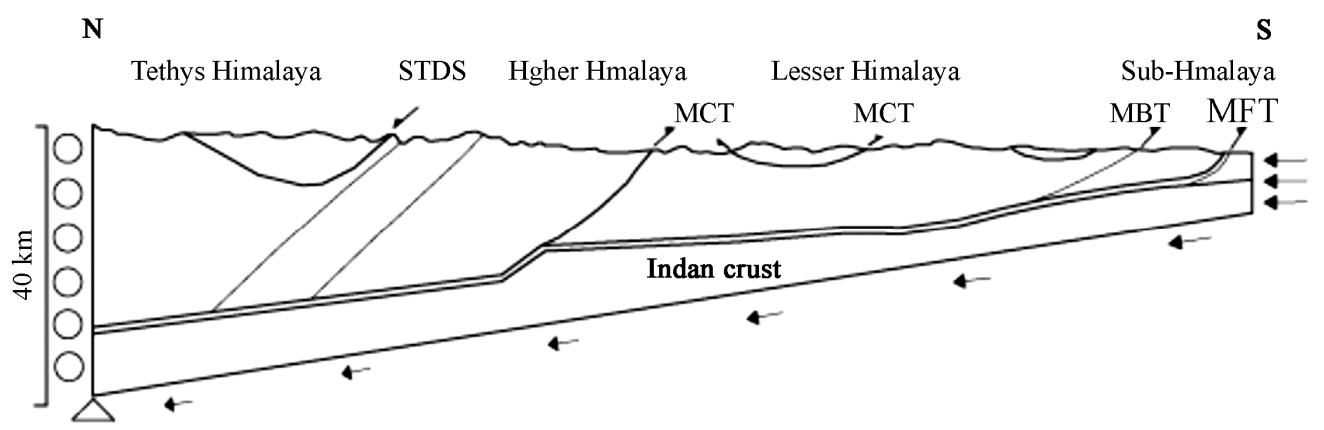

$\mathbf{N}$

(a)

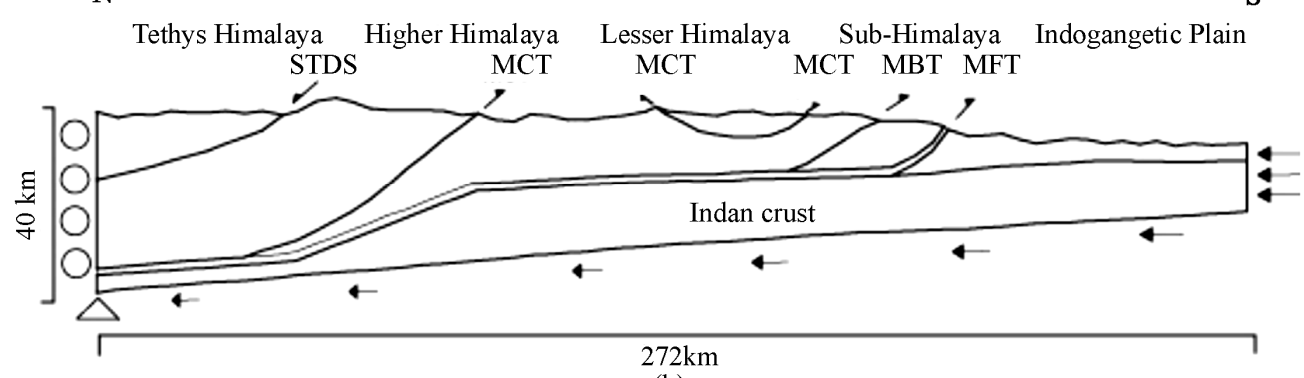

(b)

Figure 4. Simplified geological cross-sections and applied boundary conditions adopted for the modeling. (a) NW-Himalaya cross-section along A-A' and (b) western Nepal cross-section along B-B' in Figure 1. 
ment is varied in the different part of the Himalaya $[44,46]$ the uniform horizontal displacement rate of 17 $\mathrm{mm} / \mathrm{yr}$ for the NW-Himalaya and $20 \mathrm{~mm} / \mathrm{yr}$ for the western Nepal have been adopted. These convergence rates are well consistent with GPS measurements $[44,46]$ and long-term geological observations $[47,48]$ along the Himalayan front. Figure 4 shows the geometry and applied boundary conditions of our FE models based on present-day tectonic setting and kinematics of the Himalayan thrust wedge. The upper part of the entire model represents surface topography which is free to deform in all directions. The northern side of the model only can move vertically. The lowermost nodal point marked by a triangle is fixed. Since the lower boundary of the model is inclined, the convergence displacement is resolved into both $\mathrm{x}$ and $\mathrm{y}$ directions (Figure 4). The model is loaded with gravitational body force $(\mathrm{g}=9.8 \mathrm{~m} / \mathrm{s})$.

\subsection{Model Parameters}

The model consists of eight layers, which represent distinct litho-tectonic sequences of the Himalayan wedge. Each rock sequence has been assigned with distinct rock layer properties on the basis of predominant rock types as shown in Figure 5. The crustal density was obtained from published gravity-seismic model [47]. Since the density of the rock layers of the individual tectonic blocks are known, we obtained seismic P-wave $\left(V_{p}\right)$ and S-wave $\left(V_{s}\right)$ velocities for the each rock layer from the velocity models $[28,50]$. In order to solve elastic equations, we need to know the independent elastic constants Young's modulus of elasticity $(E)$ and Poisson's ratio (v) where Poisson's ratio is assumed to be constant at 0.25 for individual tectonic blocks. $E$ can be calculated by $[37,49]$ :

$$
E=\rho V_{p}^{2} \frac{(1+v)(1-2 v)}{(1-v)}
$$

Other input parameters required for modelling include the angle of internal friction $(\phi)$ and the cohesive strength $(c)$ which obtained from the handbook of physical constants [53].

\section{MODELLING RESULTS}

The series of numerical experiments were conducted for the two representative structural cross-sections of the Himalaya. Here, we present new evidence for extensional stresses and normal faulting in the several sectors of the Himalayan shallow crust. The results presented herein are based on: 1) the distribution, orientation and the magnitude of the principal stresses, 2) proximity of failure and 3) the magnitude of the shear stress and strain.

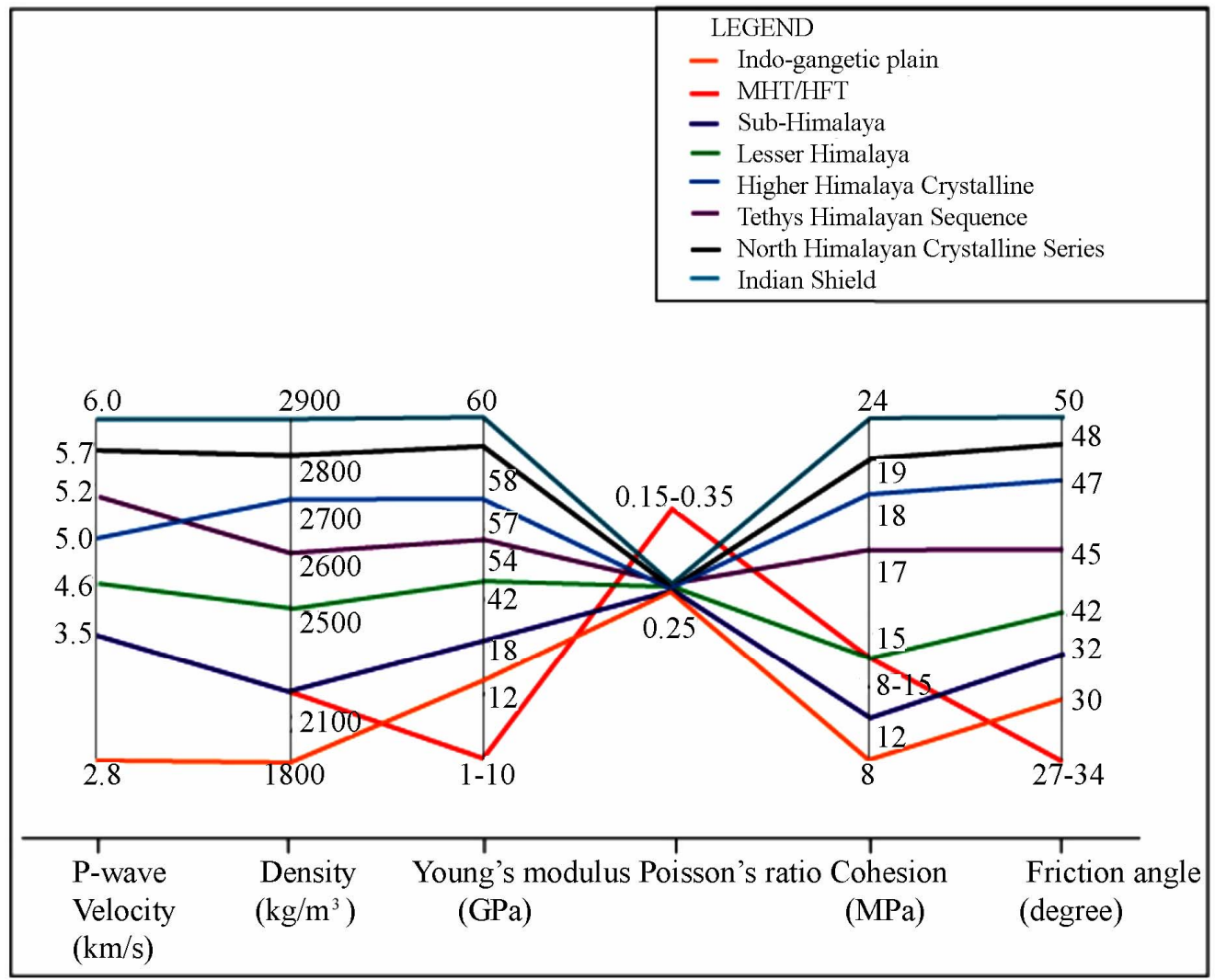

Figure 5. Physical parameters and material properties of the different rock units used for modelling. 


\subsection{Stress Distribution}

Figures 6 and 7 show the spatial distribution of the simulated stress field developed for the different horizontal convergent displacement conditions in both NWHimalaya and western Nepal models. The principal axis of maximum compressive stress $\left(\sigma_{1}\right)$ and and minimum compressive stress $\left(\sigma_{3}\right)$ are aligned in the horizontal and vertical lines, respectively. Notice that if $\sigma_{1}$ aligned in the horizontal and $\sigma_{3}$ aligned vertically represent compressional stress regime, while the orientation of $\sigma_{1}$ is vertical and $\sigma_{3}$ is horizontal together with the tensional component (red bar) implying extensional tectonic state of stress. The overall simulated stress pattern shows two distinct types of the characteristic stress field developed in the Himalayan crustal wedge. The most compressive stress regime found in the northern part, while an extensional stress develops in the southern front of the Himalaya at shallow $(<10$ in $\mathrm{km})$ crustal level. However, when increase the convergent displacement up to $500 \mathrm{~m}$ the principal axis of stress are considerably tilted and finally rotated from the original coordinate axis and the deformation front shifts progressively toward the south- ern front of the Himalaya (Figures 6(c) and 7(c)).

It is noteworthy that the change in stress field and progression of deformation shows the thrust faults have migrated from hinterland to foreland and the stress field changes from extensional to a compressional regime. In general, the predicted stress field on the Himalayan upper crust shows almost similar and uniform pattern in both models, while some discrepancy also observed in the northern part of Himalaya. In the NW-Himalaya model (Figure 6), the extensional stress field is restricted more northern part of the Himalaya whereas in the western Nepal model (Figure 7), extensional stress regime only developed south from the MCT. The stress is uniformly distributed throughout the Indian crust. Nevertheless, magnitudes of the principal stresses have increases with depth because of topographic loading.

\subsection{Maximum Shear Stress Distribution}

Figure 8 shows the distribution of maximum shear stress predicted from our modelling within the Himalayan upper crustal wedge.

The computed maximum shear stress $\left(\tau_{\max }\right)$ revealed
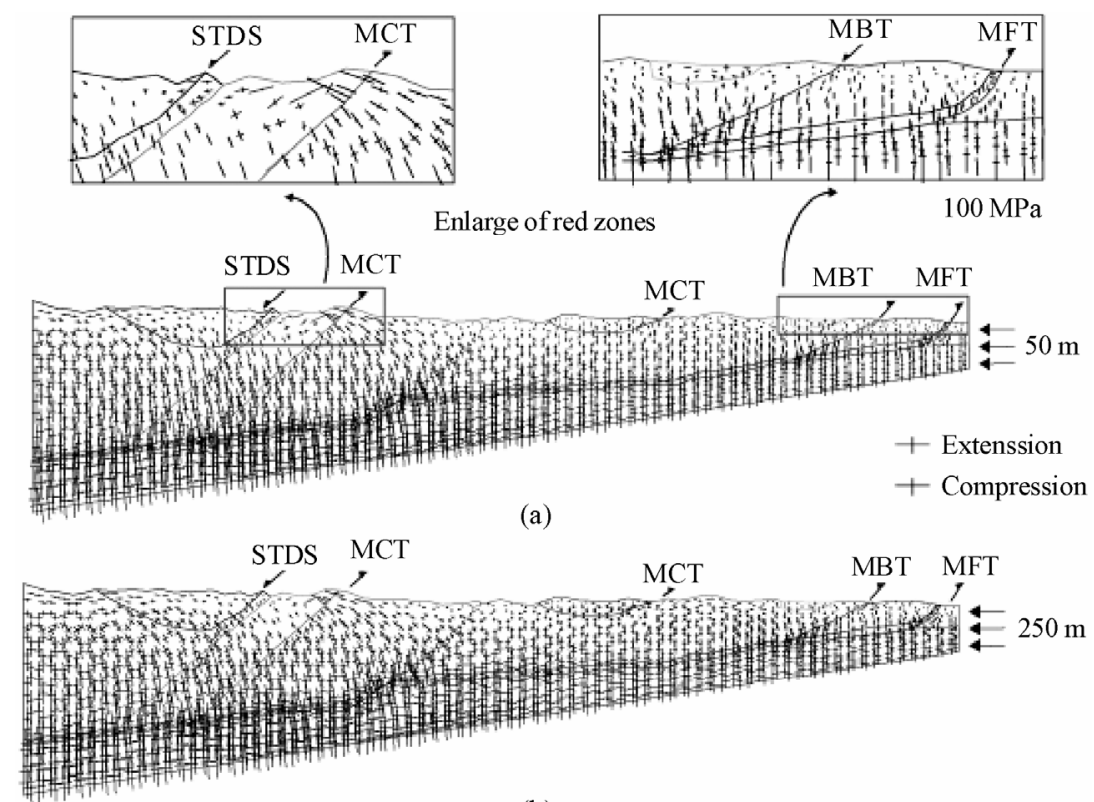

(b)

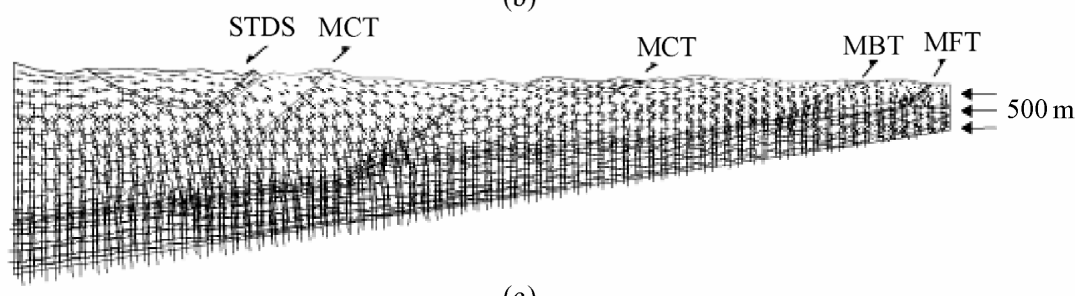

(c)

Figure 6. Predicted stress distribution in the NW-Himalaya model applying uniform convergence displacements: (a) at $50 \mathrm{~m}$; (b) at $250 \mathrm{~m}$; (c) at $500 \mathrm{~m}$. 


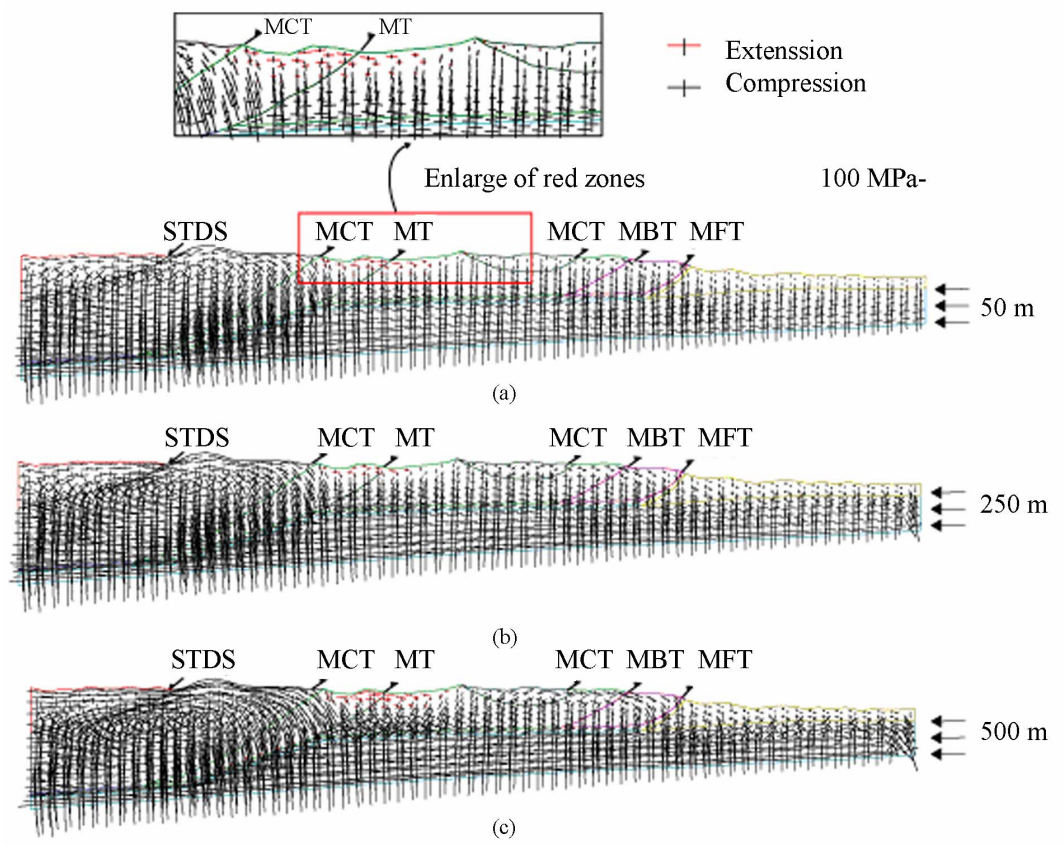

Figure 7. Predicted stress distribution in the western Nepal model applying uniform convergence displacements: (a) at $50 \mathrm{~m}$; (b) at $250 \mathrm{~m}$; (c) at $500 \mathrm{~m}$.

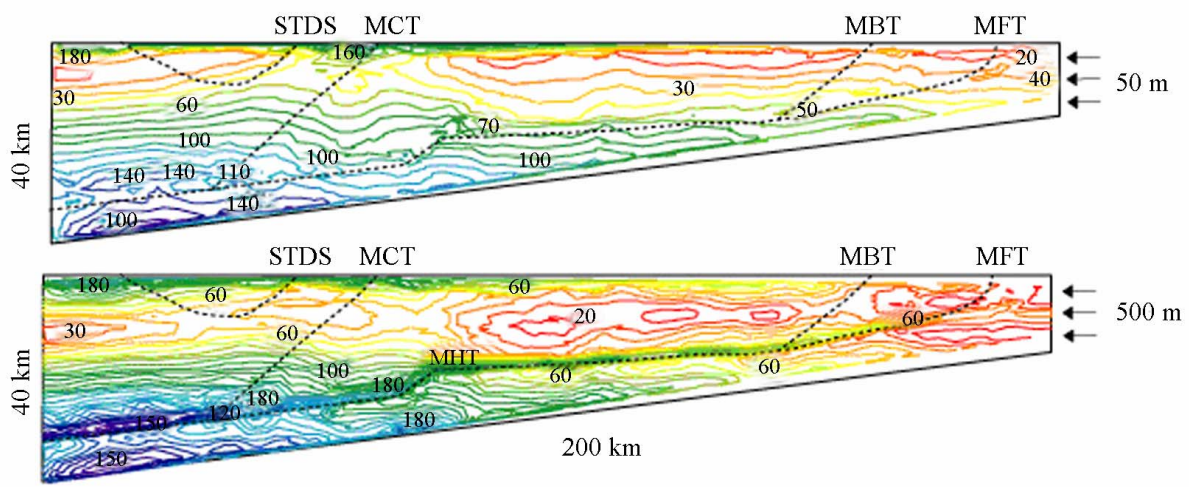

(a)

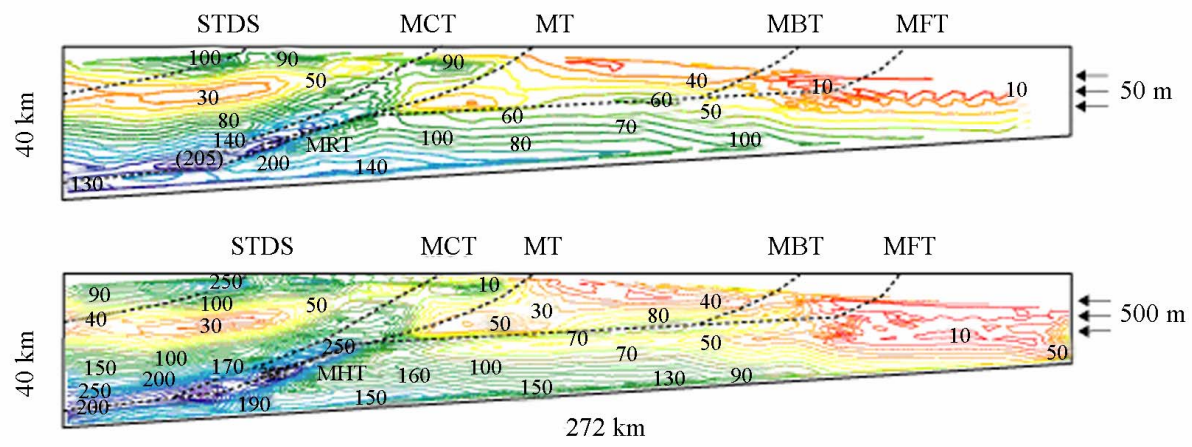

(b)

Figure 8. Predicted maximum shear stress (in MPa) distribution for (a) NW-Himalaya model and (b) western Nepal model, at $50 \mathrm{~m}$ and $500 \mathrm{~m}$ convergent displacement conditions, respectively. 


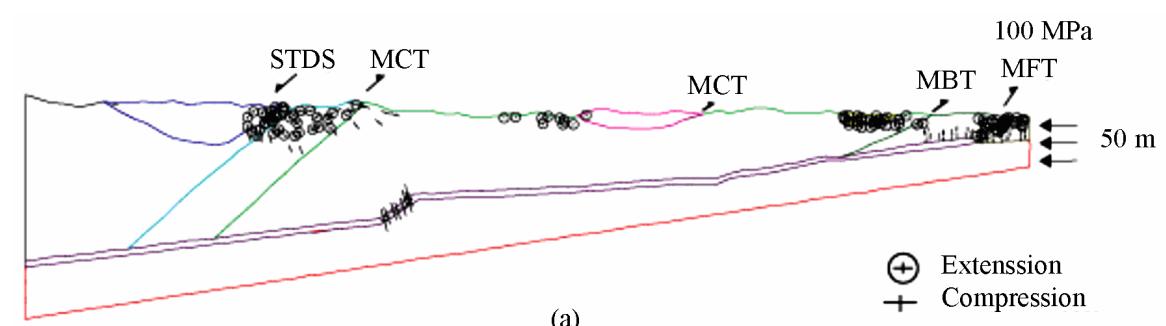

(a)

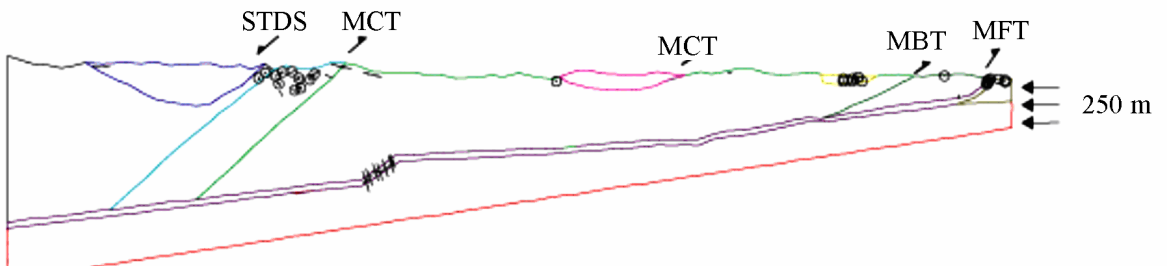

(b)

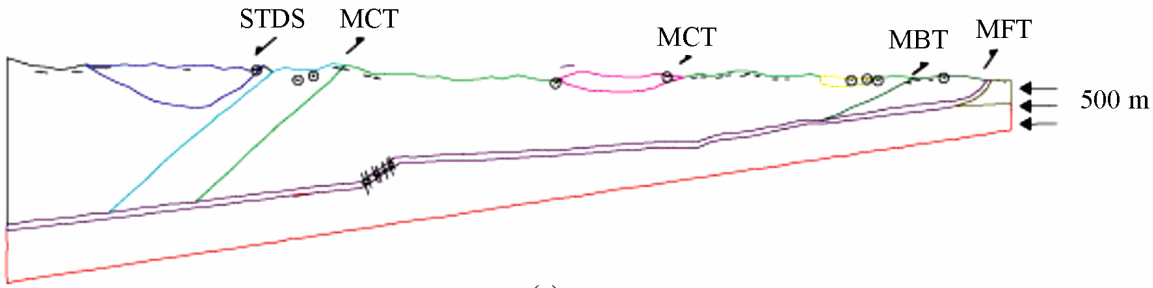

(c)

Figure 9. Predicted faulting elements in the NW-Himalaya model by imposing. (a) at $50 \mathrm{~m}$; (b) at $250 \mathrm{~m}$ and (c) at $500 \mathrm{~m}$ convergent displacements.

that the major concentration of $\tau_{\max }$ along the Himalayan basal décollement (MHT) zone. The trajectories of $\left(\tau_{\max }\right)$ along the MHT increases from the southernmost part and reach a maximum to the northern flat of the MHT ramp in both models. Our model shows that the maximum shear stress $\left(\tau_{\max }\right)$ levels of $250 \mathrm{MPa}$ and $300 \mathrm{MPa}$ from NW-Himalaya model and western Nepal model, respectively (Figure 8). This result suggests that the Himalaya has continually built up significant amounts of stress along the MHT décollement.

\subsection{Faulting Patterns}

We also examined the faulting pattern in the Himalayan brittle upper crust based on the proximity of failure. The Mohr-Coulomb failure criterion is used to determine the faulting conditions. Because in the faulting regimes $\sigma_{1}$ and $\sigma_{2}$ are nearly vertical and horizontal, the types of faulting can be easily determined using the method of Anderson [54]. Figures 9 and 10 illustrate the predicted faulting pattern for both the NW-Himalaya and western Nepal models. In general, both models demonstrate similar patterns of fault development under different horizontal convergence displacement conditions. Normally, our models clearly show two distinct types of faulting patterns in the Himalayan wedge where thrust faults are primarily concentrated in the north part (hin- terland) and normal faults are extensively developed at the southern front (foreland) of the Himalaya. Figure 9 shows failure pattern in the NW-Himalaya models from 50 to $500 \mathrm{~m}$ convergence displacement conditions. At 50 $\mathrm{m}$ horizontal convergent displacement, the modelling results show that normal faults have predicted within the Higher Himalaya, central and southernmost Lesser Himalaya and Siwalik front, while thrust faults are primarily predicted north of the MCT and in and around the MHT ramp in the Higher Himalaya. Small open circle indicates normal and pair of perpendicular lines represents thrust faults, respectively. Nonetheless, when the applied displacement gradually increases up to $500 \mathrm{~m}$, normal faults reduces considerably and thrust faults were developed in such region and progressively migrated towards the foreland. Figure $\mathbf{1 0}$ illustrates the distribution of predicted failure elements in the western Nepal model. This model shows noticeably more failure elements compared with the NW-Himalaya model. In this model, normal faults are mostly developed in the northern part of the Lesser Himalaya and the Siwalik area, where the juxtaposition of normal and thrust faulting along the ramp part of the MHT décollement is well developed at low convergent displacement (Figure 10(a)). 


\section{DISCUSSION}

Previous studies illustrate that using an elastic models are appropriate to obtain the tectonic stress field and deformation of the brittle upper crust [7,21]. Although several models have been proposed to explain the extensional state of stress and formation of the normal faults in the southern Tibet and Himalaya [7,21,22,41], but none of them explain the development of extensional stress regime and normal faults in the Himalayan front. Here, we have presented a series of experiments using 2D finite element elastic models to examine the present-day tectonic state of stress and deformation in the Himalayan upper crustal wedge. For better understanding the basic mechanism of the extensional tectonics of the overall compressive tectonic setting of the Himalayan thrust wedge we have kept the models relatively simple, and limited the model. We prescribed convergence displacement boundary conditions consistent with the contemporary plate kinematics of the central Himalaya region. We further assumed that the Himalayan upper crust behaves elastic in order to model faulting pattern of the region. Some factors are not incorporated in the current models are potentially important in the convergent tectonic belts. For example, we did not consider the effect of erosion at the surface of the Himalayan thrust wedge. However, most of syn-orogenic erosion process controls the dynamics of the orogenic wedge [55]. Despite the simplicity of the model our results may provide useful insight into extensional tectonics in the overall contractional setting of the Himalaya.

\subsection{Present-Day Stress Distribution in the Central Himalaya}

The distribution of the present-day stress field can pro- vide a significant explanation for the ongoing geodynamics and tectonic forces acting in the India-Asia collision zone. Since the convergence rate of Indian plate has been decreasing ca $40 \mathrm{Ma}$ [56], the Himalayan stress field would show consequence changes in overall compressive regime of the Himalaya. Nakata et al. [57], argue that the direction of the horizontal compressive stress axis has changed due to changes in the direction of the relative plate motion between the Indian plate and tectonic sliver. Our modelling results also support this idea and show two types of stresses developed in the Himalayan upper crustal wedge. The compressional stresses regime predicted in the northern part while extension stress regime predicted in the southern front. These stresses further retained at all convergence displacement conditions (Figures 6 and 7). Although predicted extensional stresses developed in the Himalayan front are obviously not consistent with major seismic events and dominant southward thrusting of the overall compressive setting of the Himalaya, but well corresponding with the field observations of active faulting in the several sector of Himalayan thrust wedge [14-16, 19,34], neotectonic model of Nakata [57], and focal mechanism of solutions of medium size earthquakes (Figure 11). Taking advantage from predicted extensional stress regime from our models, it can be inferred that the recent changes in compressional tectonic regime locally in the several part of the Himalayan front. Although we strongly believed that the entire orogen is still in overall compression, the predicted extensional stress regime and observed normal faults in the Himalayan frontal part are mainly due to local adjustment of tectonics regime due to the taper angle readjustment and weak Himalayan décollement. The computed stress fields

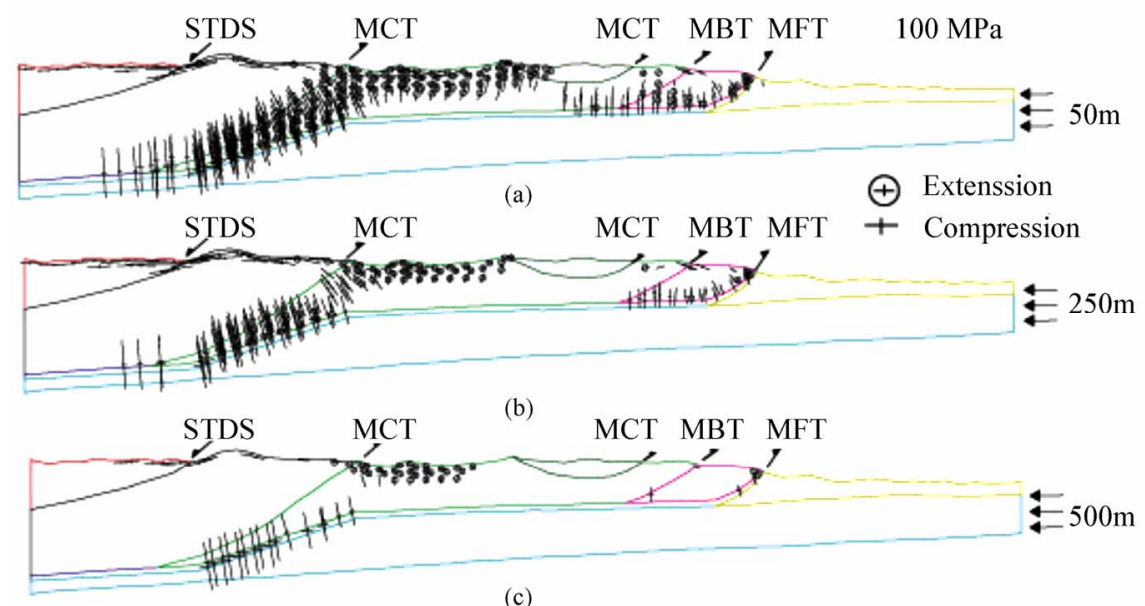

Figure 10. Predicted faulting elements in the western Nepal model by imposing different convergent displace- ment conditions for (a) at $50 \mathrm{~m}$; (b) at $250 \mathrm{~m}$; (c) at $500 \mathrm{~m}$ convergent displacements. 


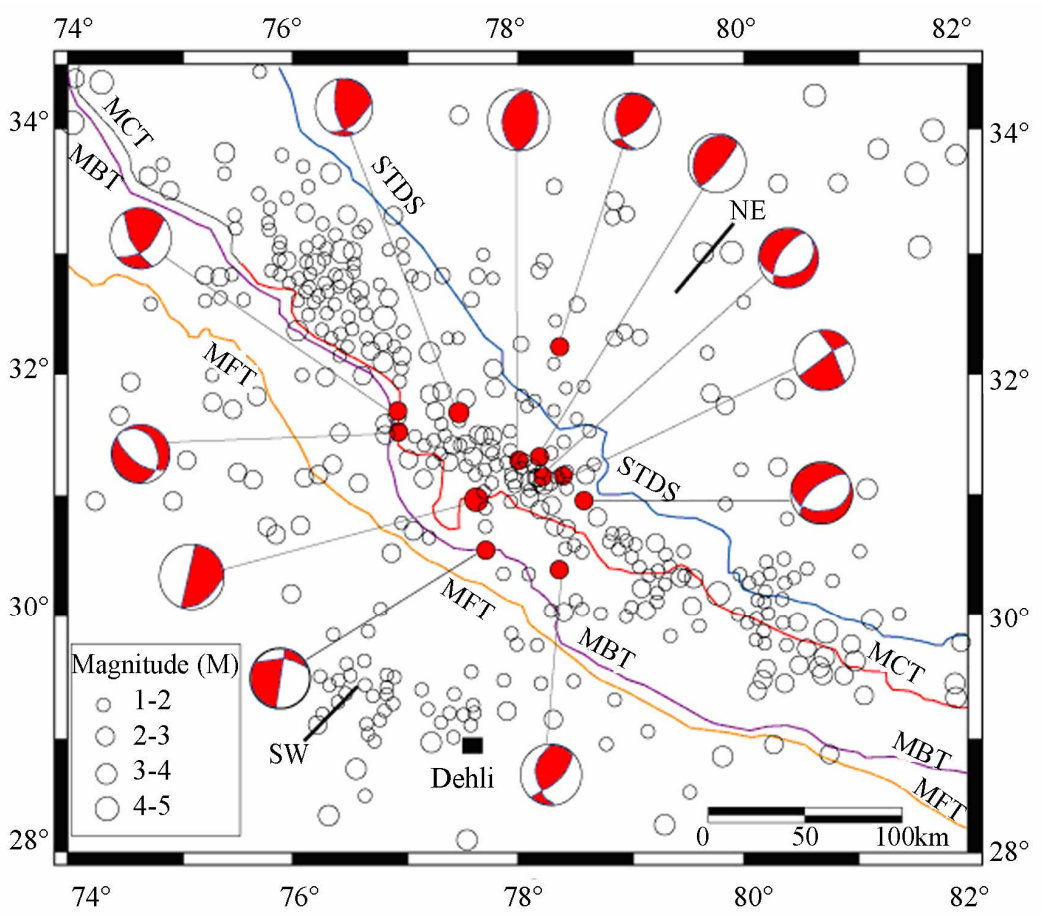

Figure 11. Focal mechanism of solutions of medium size earthquakes in NW-Himalaya adopted after Yadav et al. (2009).

show significant deflection and rotation of the maximum compressive stress $\left(\sigma_{1}\right)$ from their original horizontal position to vertical when increase the compressive displacement (Figure 7). The predicated rotation of the stress trajectories might be the effect of ramp geometry of the MHT décollement, and consistent with the seismic study of Pandey et al. [28]. In which they demonstrated that the MHT ramp acts as a geometrical barrier to changes in the orientation of the maximum principal stress in the Himalaya, causing the significant change in the stress field of the Himalaya. Nonetheless, Mugnier et al. [15] argued that if the principal stress axis deviates significantly from the horizontal, and when this deviation exceeds the dip of the vectors normal to back-tilting thrusts, the normal component of displacement may act along these faults; therefore, steep north-dipping segments of the MBT show a normal component of displacement. The rotation of the stress trajectories would facilitate the formation of imbricated thrust in the moving thrust sheet. In both models, thrusts are propagated towards the foreland of the Himalayan wedge as we increase the convergent displacement (Figures 6 and 7). This is characteristic feature of thrust propagation in fold-and-thrust belts, and consistence with fold-bendfault model of Yeats and Thakur (1998) [51].

\subsection{Magnitude of the Stresses in Central Himalaya}

Our models predicate the horizontal stress level of 300-
$500 \mathrm{MPa}$ at the depth of $40 \mathrm{~km}$ of the Indian lithosphere which is consistent with other studies [58,59]. The region with high maximum shear stress $\left(\tau_{\max }\right)$ induced will be more active [60]. If we compare both of our models; the western Nepal model shows considerable amount of maximum shear stress (300 MPa) accumulated along the MHT décollement suggests that possible major earthquake in the region due to the reactivation of the basal décollement of this part of the Himalaya. This prediction is further supported by the concentration of microseismic clusters in and around ramping part of the MHT [28], consistent with the numerical simulations [30] and GPS measurements [46].

\subsection{Development of Faulting Pattern in the Central Himalaya}

The computed results from our model predicted two types of characteristic faulting patterns developed in the Himalayan thrust wedge. In general, thrust faults are predicted in the northern Himalaya (north of MCT) while normal faults are predominantly predicted in the southern front of Himalaya for all $50 \mathrm{~m}$ to $500 \mathrm{~m}$ convergent displacements (Figures 9 and 10). According to Mugnier et al. [15] normal faults that are associated with the Himalayan major thrust structures in the frontal part of Himalaya (e.g., normal fault along the MBT) is due to a very poor strength contrast between the basal décollement and rock in wedge body and high pore fluid pres- 
sure ratios (up to 1). They further argued that the outer Himalaya extends over the width of several tens of kilometers in the central sector of Himalaya, and are presumably displaced along a décollement located in pelitic formations. There is therefore a small contrast of strength between rocks in the décollement levels and displaced sheets, a condition that favors normal faulting in the region [15]. However, Nakata et al. [57] argued that the Lesser Himalayan block is subsiding, causing normal faulting due to a change in tectonic regime of the Himalaya. From computer simulation Shankar et al. [22] proposed that the presence of a weak MHT décollement below south Tibet is the main cause of extension in the Himalaya. Our modelling results shows that the Himalayan décollement thrust (MHT) have significant role to the development of extensional state of stress and normal faulting in the Himalayan front. We believed that the formation of ramp geometry on the MHT décollement is the major causes of the development of extensional stress and normal faulting in the various part of the Himalaya fold-and-thrust belt. Moreover, we suggest that the local adjustment of the tectonic activities influenced by taper angle adjustment further influences to the formation of the extensional tectonic activities and normal faulting in the overall contractional setting of the Himalaya.

\subsection{Comparison with Field Observations}

Since our models were constrained by present-day structural sections of the Himalaya, the predicted stress regime and faulting pattern from our models can be directly compared with field observations. The simulated faulting pattern appropriately corresponds to the natural situation of the Himalaya and several faults are computed at analogous locations, which show good agreement with the position of normal faults and the extensional regime across the Himalayan thrust wedge. The stress fields and faulting pattern predicted from our model is well consistent with field observations of previous studies [13-19,22,26,37]. Our modelling results further support the formation of extension stress field and normal faulting mainly dominated in the frontal part of the Himalayan thrust wedge.

In addition, if we compare out numerical experiment results with the observations of the microseismicity and medium size earthquake focal mechanism solutions of the Himalayan front our result shows good consistency (Figure 11).

\section{CONCLUSIONS}

In this paper, the $2 \mathrm{D}$ finite element modelling was used to simulate the present-day extensional tectonic state of stresses and deformation in the overall compressional setting of the Himalayan brittle upper crust incorporated an elastic rheology under plain strain condition. Based on our modelling results, compared with geological field observations, records of active normal faults and the in situ stress regime, we conclude that the extensional tectonic regime and normal faulting of the Himalaya is not only restricted within the southern Tibet but distributed throughout the Himalayan thrust wedge as observed in field. Modelling results further indicate that the extensional tectonic deformation in the brittle upper crust of the Himalayan thrust wedge is still active; although the overall tectonic setting of the Himalaya is in compression. Our results show that the MHT décollement plays a pivotal role in changing the tectonic stress field and faulting regime in the Himalayan thrust wedge, and accumulating significant amount of stress/strain along the ramp part. This continuous process of the stress/strain accumulation along the MHT décollement triggers intense microseismic activities, and increases the risk of the future great earthquake in the central Himalayan region.

\section{ACKNOWLEDGEMENTS}

The Ministry of Education, Culture, Science and Technology (Monbukagakusho) of Japan is acknowledged for the financial support of the first author. The authors are thankful to Prof. Laurent Godin, Dawn Kellett and P. Mandal for their valuable comments and suggestions, which greatly helped to improve the earlier version of the manuscript.

\section{REFERENCES}

[1] Ratschbacher, L., Frisch, W., Neubauer, F., Schmid, S.M. and Neugebauer, J. (1989) Extension in compressional orogenic belt: The eastern Alps, Geology, 17(5), 404-407.

[2] Corredor, F. (2003) Eastward extend of the late eoceneearly oligocene onset of deformation across the northern Andes: constraints from the northern portion of the Eastern Cordillera fold belt, Colombia. Journal of South American Earth Sciences, 16(6), 445-457.

[3] Caiazzo, C., Ascione, A. and Cinque, A. (2006) Late tertiary-quaternary tectonics of the southern-apennines (Italy): New evidences from the Tyrrhenian slop. Tectonophysics, 421(1-2), 23-51.

[4] Norton, M. (1986) Late Caladonian extension in western Norway: A response to extreme crustal thickening. Tectonics, 5(2), 192-204.

[5] Hodges, K.V. and Walker, J.D. (1992) Extension in the cretaceous Sevier Oroben, North American Cordillera. Geology, 104(5), 560-569.

[6] Burg, J.P., Brunel, M., Gapais, D., Chen, G.M. and Liu, G.H. (1984) Deformation of leucogranites of the crystalline main central thrust sheet in southern Tibet (China). Journal of Structural Geology, 6, 219-223. 
[7] Royden, L.H. and Burchfiel, B.C. (1987) Thin skinned $\mathrm{N}-\mathrm{S}$ extension within the convergence Himalayan region; Gravitational collapse of a Miocene topographic front. In: Continental Extensional Tectonics, Croward, M.P., Dewey, J.F. and Hanback, P.L., Eds., Geological Society London, 26(5-6), 611-619.

[8] Hodges, K.V., Parrish, R., Housh, T., Lux, D., Burchfiel, B.C., Royden, L. and Chan, Z. (1992) Simultaneous Miocene extension and shortening in the Himalayan origin. Science, 258(5087), 1466-1470.

[9] Gansser, A. (1964) Geology of the Himalayas. Wiley Inter-Science, New York, 289.

[10] Molnar, P. and Lyon-Caen, H. (1988) Some simple physical aspects of the support, structure, and evolution of mountain belts. In: Clark, S., Burchfiel, B.C. and Suppe, J., Eds., Processes in Continental Lithospheric Deformation, Geological Society of America Special Paper, 218, 179-207.

[11] Le Fort, P. (1975) Himalayas, the collided range: Present knowledge of the continental arc. American Journal of Science, 275(A), 1-44.

[12] Joshi G.R. and Hayashi, D. (2008b). Numerical modelling of neotectonic movements and state of stresses in the central Seismic Gap region, Garhwal Himalaya. Journal of Mountain Science, 5(4), 279-298.

[13] Hodges, K., Bowring, S., Davidek, K., David Hawkins, D. and Krol, M. (1998) Evidence for rapid displacement on Himalayan normal faults and the importance of tectonic denudation in the evolution of mountain ranges. Geology, 26(6), 483-486.

[14] Nakata, T. (1989) Active faults of Himalaya of India and Nepal. Geological Society of America, 332(1), 243-264.

[15] Mugnier, J.-L., Huyghe, P., Chalaron, E. and Mascle, G. (1994) Recent movements along the main boundary thrust of the Himalayas: Normal faulting in an overcritical thrust wedge? Tectonophysics, 238(1-4), 199-215.

[16] Thakur, V.C., Rautela, P. and Jafaruddin, M. (1995) Normal faults in pinjor thrust zone in Lesser Himalaya and between the higher Himalaya Crystallines and Chamba sequence in Kashmir Himalaya, India. Earth Planetary Science, 104(3), 499-508.

[17] Vanney, J., Grasemann, B., Rahn, M., Frank, W., Carter, A., Baudraz, V. and Cosca, M. (2004) Miocene to Holocene exhumation of metamorphic crustal wedges in the NW Himalaya: Evidence for tectonic extrusion coupled to fluvial erosion. Tectonics, 23(1), 1-24.

[18] Vanney, J. and Grasemann, B. (2001) Himalayan inverted metamorphism and syn-convergence extension as a consequence of a general shear extrusion. Geological Magazine, 138(3), 253-276.

[19] Philips, G. and Virdi, N.S. (2006) Co-existing compressional and extensional regiems along the Himalayan front vis-à-vis active fault near Singhauli, Haryana, India; Active faults and neotectonic activity in the Panjour Dun, Northwestern Frontal Himalaya. Current Science, 90(9), 1267-1271.

[20] Vanbrabant, Y, Jongmans, D., Hassani, R. and Bellono, D. (1999) An application of two-dimensitional finite-element modelling for studying the deformation of the Vriscan fold-and-thrust belt (Belgium). Tectonophysics, 309(1-4), 141-159.

[21] Yin, A. (1993) Mechanics of wedge shaped fault blocks an elstic solution for compressional wedge. Journal of Geophysical Research, 98(B8), 14245-14256.

[22] Shankar, D., Kapur, N. and Singh, B. (2002) Thrustwedge mechanics and coeval development of normal and reverse faults in the Himalayas. Journal of Geological Society, 137(1), 1-34.

[23] Beaumont, C., Jamieson, R.A., Nguyen, M.H. and Lee, B. (2001) Himalayan tectonics explained by extrusion of a low-viscosity crustal channel coupled to focus surface denudation. Nature, 414(6865), 738-742.

[24] Jamieson, R.A., Beaumont, C., Medvedev, S. and Nguyen, M.H. (2004) Crustal channel flows: Numerical models with implications for metamorphism in the Himalayan-Tibetan Orogen. Journal of Geophysical Research, 109(B06407), 1-24.

[25] Zhao, W., Nelson, K.D. and Team, P.I. (1993) Deep seismic reflection evidence for continental underthrusting beneath southern Tibet. Nature, 366(6455), 557-559.

[26] Schelling, D. and Arita, K. (1991) Thrust tectonics, crustal shortening and the structure of the far eastern Nepal Himalaya. Tectonics, 10(5), 851-862.

[27] Srivastava, P. and Mitra, G. (1994) Thrust geometries and deep structure of the outer and inner Lesser Himalaya, Kumaun and Garhwal (India): Implications for evolution of the Himalayan fold-and-thrust belt. Tectonics, 13(1), 89-109.

[28] Pandey, M.R., Tandukar, R.P., Avouac, J.P., Leve, J. and Massot, P. (1995) Interseismic stress accumulation on the Himalayan crustal ramp (Nepal). Geophysical Research Letter, 22(16), 751-754.

[29] Yeats, R.S., Nakata, T., Farah, A., Fort, M., Miza, M.A., Pandey, M.R. and Stein, R.S. (1992) The Himalayan frontal fault system. Annales Tectonicas, 6(Suppl.), $85-98$.

[30] Berger, A., Jouanne, F., Hassani, R.D. and Mugnier, J.L. (2004) Modelling the spatial distribution of the present-day deformation in Nepal: How cylindrical is the main Himalayan thrust in Nepal? Geophysical Journal International, 156(1), 94-114.

[31] Searle, M.P., Law, R.D., Godin, L., Larson, K.P., Streule, M.J., Cottle, J.M. and Jessup, M.J. (2008) Defining the Himalayan main central thrust in Nepal. Journal of the Geological Society, 165(2), 523-534.

[32] Meigs, A.J., Douglas, W., Burbank, B. and Beck, A.B. (1995) Middle-late Miocene (> $10 \mathrm{Ma}$ ) formation of the main boundary thrust in the western Himalaya. Geology, 23(5), 423-426.

[33] Valdiya, K.S. (2001) Reactivation of terrene-defining boundary thrusts in central sector of the Himalaya: Implications. Current Science, 81(11), 1418-1431.

[34] Malik, J.N. and Nakata, T. (2003) Active faults and related late quaternary deformation along the Northwestern Himalayan Frontal zone, India. Analysis of Geophysics, 46(5), 917-936.

[35] Kumar, S., Wesnousky, W.S., Rockwell, T.K., Ragona, D., Thakur, V.C. and Seitz, G. (2001) Earthquake recurrence and rupture dynamics of the Himalayan Frontal thrust, India. Science, 294(5550), 2328-2331.

[36] Philip, G. and Sah, M.P. (1999) Geomorphic Signatures for active tectonics in the Trans Yamuna segment of the western Doon Valley, NW Himalaya. International Journal of Applied Earth Observation and Geoinforma- 
tion, 1(1), 54-63.

[37] Malik, J.N. and Mohanty, C. (2007) Active tectonic influence on the evolution of drainage and landscape: Geomorphic signatures from frontal and hinterland areas along the Northern Himalaya, India. Journal of Asian Earth Sciences, 29(5-6), 604-618.

[38] Hayashi, D. (2008) Theoretical basis of FE simulation software package. Bulletin Faculty of Science University of the Ryukyus, 85(3), 81-95.

[39] Joshi G.R. and Hayashi D. (2008) Neotectonic deformation and shortening along the Himalayan front in the Garhwal region by finite element modelling. Bullettino di Geofisica Teorica ed Applicacate, 49(Suppl.2), 228-233.

[40] Joshi G.R. and Hayashi, D. (2010). Finite element modelling of the pull-apart formation: Implication for tectonics of Bengo Co pull-apart basin, Southern Tibet. Natural Science, 2(6), 654-666.

[41] Wang, K., He, J. and Devis, E.E. (1997) Transform puss, oblique subduction resistance, and intraplate stress of the Juan de Fuca plate. Journal of Geophysical Research, 102(B1), 661-674.

[42] Melosh, F.J. and Williams, C.A. (1989) Mechanics of graben formation in crustal rocks: A Finite element analysis. Journal of Geophysical Research, 94(B10), 1396113973.

[43] Ni, J. and Barazangi, M. (1984) Seismotectonics of the Himalayan collision zone; Geometry of the underthrusting Indian plate beneath the Himalaya. Journal of Geophysical Research, 89(B8), 1147-1163.

[44] Bilham, R., Larson, K., Freymueller, J., et al. (1997) GPS measurements of present-day convergence across the Nepal Himalaya. Nature, 386(6620), 61-64.

[45] DeMets, C., Gordon, R.G., Argus, D.F. and Stein, S. (1994) Effect of recent revisions to the geomagnetic reversal time scale on estimates of current plate motions. Geophysical Research Letter, 21(20), 2191-2194.

[46] Banerjee, P. and Bürgmann, R. (2002) Convergence across the northwestern Himalaya from GPS measurements. Geophysical Research Letters, 29(20), 30-34.

[47] Wesnousky G.S., Kumar, S., Mohindra, R. and Thakur, V.C. (1999) Uplift and convergence along the Himalayan frontal thrust of India. Tectonics, 18(6), 967-976.
[48] Lave, J. and Avouac, J.P. (2000) Active folding of fluvial terraces across the Siwalik Hills, Himalayas of Central Nepal. Journal of Geophysical Research, 105(B3), 57355770.

[49] Hetényi, G., Cattin, R., Brunet, F., Bollinger, L., VergenJone, J., Nábělek, L. and Diament, M. (2007) Density distribution of the India plate beneath the Tibetan plateau: Geophysical and petrological constraints on the kinetics of lower-crustal eclogitization. Earth and Planetary Science Letter, 264(1-2), 226-244.

[50] Cotton, F., Compillo, M., Deschamps, A. and Rastogi, B. K. (1996) Rupture history and seismotectonics of the 1991 Uttarkashi, Himalaya earthquake. Tectonophysics, 258(1-4), 35-51.

[51] Yeats, R. and Thakur, V.C. (1998) Reassessment of earthquake hazard based on a fault-bend-fold model of the Himalayan plate-boundary fault. Current Science, 74(3), 230-233.

[52] Timoshenko, S.P. and Goodier, J.N. (1970) Theory of Elasticity, McGraw-Hill Book Company, 3rd Edition, London, 567-588.

[53] Clark, S.P., Jr., Ed. (1966) Handbook of Physical Constants, Geological Society America, Memoir, 97, 587.

[54] Anderson, E.M. (1951) The dynamics of faulting and dike formation with application to Britain. Oliver and Boyd, 2nd Edition, Edinburgh, 133-147.

[55] Dahlen, F.A. and Suppe, J. (1988) Mechanics, growth and erosion of mountain belts. Processes in Continental Lithospheric Deformation, Geological Society of America, 218(1-2), 161-178.

[56] Patrait, M.R. and Achache, J. (1984) India-Eurasia collision chronology and its implications for crustal shortening and driving mechanisms of the plates. Nature, 311(18), 615-621.

[57] Nakata, T., Otsuki, K. and Khan, S.H. (1990) Active faults, stress field and plate motion along the Indo-Eurasian plate boundary. Tectonophysics, 181(1-4), 83-95.

[58] Wills, S. and Buck, W.R. (1997) Stress field rotation and rooted detachment faults: A coulomb failure analysis. Journal of Geophysical Research, 102(B9), 2050320514. 